\title{
EFFECT OF FOLLICULAR FLUID AND OESTRADIOL ON THE LUTEINIZATION OF RAT GRANULOSA CELLS IN VITRO
}

\author{
J. BERNARD \\ Laboratoire de Physiologie de la Reproduction, C.N.R.S. E.R. 122, \\ Hopital de Bicêtre, 94270 Bicêtre, France
}

(Received 14th October 1974)

\begin{abstract}
Summary. The effect of pig follicular fluid (FF), total or oestrogenfree, and of oestradiol-17 $\beta$ on the luteinization and progesterone secretion of rat granulosa cells was investigated during 4 days in culture. Both FF and oestrogen-free FF modified the differentiation of the granulosa cells, particularly their size and the appearance of their nucleoli. Addition of total FF or oestradiol- $17 \beta(50,100$ or $500 \mathrm{ng} / \mathrm{ml})$ to the control medium markedly increased the progesterone secretion of the granulosa cells, but oestrogen-free $\mathbf{F F}$ and dialysed fetal calf serum had no effect. It was concluded that (1) FF could modify the morphological changes of the rat granulosa cells in vitro, but could not inhibit their secretion of progesterone, (2) the granulosa cells were able to synthesize progesterone regardless of their stage of differentiation, (3) oestradiol$17 \beta$ had a direct stimulatory effect on progesterone secretion by granulosa cells in vitro. The possible mode of action of FF upon luteinization is discussed.
\end{abstract}

\section{INTRODUCTION}

Luteinization in vitro is a spontaneous phenomenon which has been described for granulosa cells recovered from the preovulatory follicles of women (Channing, 1969a), monkeys (Channing, 1970a), horses (Channing, 1969b), pigs (Channing, 1970b; Schomberg, 1969), rabbits (Nicosia, 1972), rats (Nekola \& Nalbandov, 1971; Bernard, 1972) and mice (Grob, 1971). After a few days in culture, these cells acquire the morphological characteristics of the luteal cells and secrete progesterone; this secretion can be increased by the gonadotrophic hormones, LH in particular, the effect of which appears to be mediated by cyclic AMP (Channing, 1973).

The reason for the spontaneous luteinization of the granulosa cells in vivo or in vitro is still unknown. According to El-Fouly, Cook, Nekola \& Nalbandov (1970), the oocyte may secrete into the follicular fluid (FF) a factor exerting a repressive effect on the luteal differentiation of the granulosa cells: the absence of this factor after ovulation or during culture would permit these cells to luteinize. To verify this hypothesis, the effect of FF on the luteal differentiation of 
rat granulosa cells has been studied, and observations indicating that this fluid seems to contain a factor which modifies the behaviour of these cells in vitro have been reported elsewhere (Bernard, 1973).

The present paper reports some complementary information confirming this interpretation and the results of a study on the effect of $\mathrm{FF}$ and of oestradiol on the secretion of progesterone in vitro by the granulosa cells of the rat.

\section{MATERIALS AND METHODS}

\section{Follicular fluid}

The fluid was aspirated from pig follicles of approximately $15 \mathrm{~mm}$ in diameter about $2 \mathrm{hr}$ after the animals were killed. After centrifugation, part of this fluid was incubated for $2 \mathrm{hr}$ at $37^{\circ} \mathrm{C}$ in the presence of $10 \%$ dextran-coated charcoal in tris-EDTA buffer in order to eliminate the oestrogens by adsorption, according to the technique of differential dissociation (Murphy, 1967). The total FF and the oestrogen-free FF were both stored at $-30^{\circ} \mathrm{C}$.

\section{Recovery of the granulosa cells}

Female rats of the Wistar strain (24 to 25 days old) were given a subcutaneous injection of 30 i.u. PMSG and killed 51 to $53 \mathrm{hr}$ later. The ovaries were removed under sterile conditions and placed in TC medium 199 containing $200 \mu \mathrm{g}$ streptomycin $/ \mathrm{ml}$ and 200 i.u. penicillin $/ \mathrm{ml}$. The mature follicles were ruptured under a stereomicroscope in order to free the granulosa fragments. These fragments were then collected with the aid of a Pasteur pipette and rinsed twice in TC medium 199.

\section{Incubations}

The granulosa fragments were transferred on coverslips into Leighton tubes and incubated in a mixture of air and $5 \% \mathrm{CO}_{2}$ in $1 \mathrm{ml}$ of a 'control medium' consisting of $90 \%$ TC medium 199 (Difco), 10\% dialysed fetal calf serum (Gibco), $100 \mu \mathrm{g}$ streptomycin/ml, 100 i.u. penicillin/ml, $3 \mathrm{~g} \mathrm{NaHCO} /$ litre. The cells from a single ovary were enough to inoculate two tubes of culture.

In certain experiments, oestradiol-17 $\beta$ was added to the control medium in final concentrations of 50,100 or $500 \mathrm{ng} / \mathrm{ml}$. In other experiments, the FF (total or after adsorption by charcoal) was added to the control medium in a final concentration of $50 \%$ and the cells were incubated in these media under the same conditions as the experiments described above. Controls were incubated in the presence of dialysed fetal calf serum at a final concentration of $50 \%$.

The media were not renewed during the experiments.

\section{Methods of analysis}

Histology. After 2 and 4 days of incubation, the cells were fixed with $10 \%$ neutral formol saline and stained with May-Grünwald-Giemsa for routine morphological study, or with Sudan red for the detection of lipids.

Progesterone assays. The progesterone secreted by the cells after 2 and 4 days in culture and that contained in the incubation media was estimated by a 
competitive protein-binding assay with the progesterone-binding plasma protein (PBP), according to the method of Pichon \& Milgrom (1973). The high specificity and the sensitivity ( $0.1 \mathrm{ng}$ progesterone) of this method allows a dosage of progesterone after a single extraction by hexane without prior purification by chromatography.

\section{RESULTS}

Histology

After incubation for 2 days in the control medium, the granulosa cells started to spread on the coverslips. The cells were small and polygonal, with a large nucleus containing a fragmented, pale and scarcely visible nucleolus, and with few inclusions in the cytoplasm. Thereafter, the cells continued to spread and on the 4th day the size of the cells had increased considerably: lipid droplets stained with the Sudan red and numerous granules were present in the cytoplasm; the nucleus had a round or oval shape and contained one to four large and prominent nucleoli (Pl. 1, Fig. 1).

After 2 days in culture in the presence of FF, some of the granulosa cell fragments had not adhered to the coverslips and, though viable, remained suspended in the medium. Those fragments which adhered were composed of small cells which did not spread except at the periphery. After incubation for 4 days, the discrepancy between the growth of these cells compared to those in the control medium was maintained and the cells were three to four times smaller than control cells of the same age. There were, however, numerous lipid droplets in the cytoplasm; the nuclei of the cells near the centre of a granulosa fragments were round in shape and still contained only one small nucleolus (Pl. 2, Fig. 2), while the nucleoli of the cells located peripherally were usually oval in shape and contained a fragmented and scarcely visible nucleolus (PI. 2, Fig. 3). In the presence of oestrogen-free FF, the same morphological characteristics were observed as in the presence of the total FF (Pl. 2, Fig. 4).

In the presence of oestradiol, the development of the granulosa cells was the same as that of the cells incubated in the presence of control medium, but in some cases, there were more lipid droplets in the cytoplasm (Pl. 2, Fig. 5).

The development of the cells in the presence of fetal calf serum at a final concentration of $50 \%$ was identical to that of the cells incubated in the presence of the control medium: outgrowth, increase in cell size, appearance of granules and lipid droplets in the cytoplasm, appearance of one or more well-differentiated nucleoli (Pl. 2, Fig. 6). As in the case of the cells incubated in the presence of FF, however, some of the cells did not adhere to the coverslips but remained in suspension in the medium.

In some cultures, whatever the type of incubation, oocytes were observed fixed on the coverslips and surrounded by their corona radiata. After 4 days in culture, the morphology of the granulosa cells of this corona seemed to have undergone no change and resembled that of the cells incubated in FF: the cells remained small, were situated in a concentric layer around the oocyte, and their nuclei were rounded and contained only one small nucleolus (Pl. 2, Fig. 7). 
Progesterone assays

The results of the assays performed before incubation of the cells and after incubation for 2 and 4 days are given in Table 1. Each value corresponds to the amount of progesterone secreted by the cells from a single ovary and present in $1 \mathrm{ml}$ medium.

Table 1. Levels of progesterone $(\mathrm{ng} / \mathrm{ml})$ secreted by rat granulosa cells cultured in different media

\begin{tabular}{|c|c|c|c|c|}
\hline \multirow{2}{*}{$\begin{array}{c}\text { Culture medium } \\
\text { (NNo. of experiments })\end{array}$} & \multirow[t]{2}{*}{ Before incubation } & \multicolumn{2}{|c|}{ After incubation for: } & \multirow{2}{*}{$\begin{array}{l}\text { Daily } \\
\text { progesterone } \\
\text { secretion }\end{array}$} \\
\hline & & 2 days & 4 days & \\
\hline Control medium* (5) & $\begin{array}{l}2 \cdot 2 \pm 0.9 \\
1 \cdot 0 \pm 0.2 \\
4 \cdot 0 \pm 1 \cdot 7 \\
2 \cdot 4 \pm 0 \cdot 1 \\
2 \cdot 3 \pm 0.6\end{array}$ & $\begin{array}{l}158 \cdot 9 \pm 37 \cdot 3 \\
337.5 \pm 123.7 \\
271 \cdot 1 \pm 28 \cdot 0 \\
343.9 \pm 37.4 \\
291 \cdot 0 \pm 28 \cdot 1\end{array}$ & $\begin{array}{l}402 \cdot 9 \pm 10.7 \\
400 \cdot 0 \pm 70 \cdot 7 \\
542 \cdot 0 \pm 56.5 \\
555 \cdot 5 \pm 112 \cdot 2 \\
\mathbf{7 7 3 . 8} \pm 102 \cdot 8\end{array}$ & $134 \cdot 6 \pm 35$ \\
\hline $\begin{array}{l}\text { Control medium }+50 \mathrm{ng} \\
\text { oestradiol- } 17 \beta / \mathrm{ml} \text { (3) }\end{array}$ & $\begin{array}{l}8 \cdot 7 \pm 5 \cdot 3 \\
2 \cdot 4 \pm 0 \cdot 1 \\
2 \cdot 3 \pm 0 \cdot 6\end{array}$ & $\begin{array}{l}606 \cdot 0 \pm 26 \cdot 8 \\
833 \cdot 3 \pm 56 \cdot 1 \\
423 \cdot 3 \pm 74 \cdot 8\end{array}$ & $\begin{array}{l}1625 \cdot 2 \pm 44 \cdot 2 \\
1455 \cdot 0 \pm 187 \cdot 0 \\
1005 \cdot 3 \pm 74 \cdot 8\end{array}$ & $325 \cdot 5 \pm 15$ \\
\hline $\begin{array}{l}\text { Control medium }+100 \mathrm{ng} \\
\text { oestradiol-17 } \beta / \mathrm{ml}(1)\end{array}$ & $2 \cdot 4 \pm 0 \cdot 2$ & $661 \cdot 4 \pm 2 \cdot 0$ & $1561 \cdot 3 \pm 261 \cdot 2$ & $358 \cdot 0 \pm 40$ \\
\hline $\begin{array}{l}\text { Control medium }+500 \mathrm{ng} \\
\text { oestradiol-17 } / \mathrm{ml}(1)\end{array}$ & $2 \cdot 3 \pm 0 \cdot 2$ & $582 \cdot 0 \pm 149 \cdot 6$ & $1560 \cdot 8 \pm 486 \cdot 3$ & $338 \cdot 4 \pm 48$ \\
\hline $\begin{array}{l}\text { Control medium containing } \\
50 \% \text { total follicular fluid }(5)\end{array}$ & $\begin{array}{c}46 \cdot 5 \pm 4 \cdot 5 \\
260 \cdot 9 \pm 5 \cdot 6 \\
186 \cdot 2 \pm 35 \cdot 3 \\
333 \cdot 7 \pm 30 \cdot 0 \\
555 \cdot 5 \pm 112 \cdot 2\end{array}$ & $\begin{array}{c}542 \cdot 6 \pm 15 \cdot 5 \\
569 \cdot 5 \pm 131 \cdot 1 \\
1668 \cdot 7 \pm 167.9 \\
1456 \cdot 2 \pm 132 \cdot 6 \\
1574 \cdot 1 \pm 355 \cdot 4\end{array}$ & $\begin{array}{l}1525 \cdot 0 \pm 176 \cdot 7 \\
1523 \cdot 2 \pm 280 \cdot 9 \\
3025 \cdot 0 \pm 636 \cdot 4 \\
2118 \cdot 7 \pm 150 \cdot 3 \\
2910 \cdot 0 \pm 322 \cdot 4\end{array}$ & $291 \cdot 5 \pm 105$ \\
\hline $\begin{array}{l}\text { Control medium containing } \\
50 \% \text { oestrogen-free follicular } \\
\text { fluid (4) }\end{array}$ & $\begin{array}{l}25 \cdot 6 \pm 2 \cdot 3 \\
20 \cdot 1 \pm 3 \cdot 0 \\
39 \cdot 7 \pm 11 \cdot 2 \\
31 \cdot 7 \pm 7 \cdot 5\end{array}$ & $\begin{array}{l}462 \cdot 5 \pm 88 \cdot 4 \\
124 \cdot 9 \pm 11 \cdot 2 \\
396 \cdot 8 \pm 37 \cdot 4 \\
224 \cdot 8 \pm 93 \cdot 5 \\
\end{array}$ & $\begin{array}{l}562 \cdot 5 \pm 159 \cdot 1 \\
327 \cdot 5 \pm 48 \cdot 3 \\
753 \cdot 9 \pm 56 \cdot 1 \\
731 \cdot 7 \pm 37 \cdot 4 \\
\end{array}$ & $120 \cdot 5 \pm 43$ \\
\hline $\begin{array}{l}\text { Control medium containing } \\
50 \% \text { dialysed fetal calf serum } \\
\text { (3) }\end{array}$ & $\begin{array}{r}11 \cdot 8 \pm 0 \cdot 8 \\
6 \cdot 5 \pm 0 \cdot 1 \\
6 \cdot 4 \pm 1 \cdot 2\end{array}$ & $\begin{array}{l}243 \cdot 7 \pm 44 \cdot 2 \\
312 \cdot 5 \pm 53 \cdot 0 \\
127 \cdot 5 \pm 12 \cdot 3\end{array}$ & $\begin{array}{l}300 \cdot 0 \pm 70 \cdot 7 \\
700 \cdot 0 \pm 212 \cdot 1 \\
514 \cdot 2 \pm 43 \cdot 4\end{array}$ & $111 \cdot 7 \pm 40$ \\
\hline
\end{tabular}

Values are expressed as Means \pm S.E.M.

* See text for d'etails of composition.

$\uparrow$ Values after subtraction of the initial progesterone content.

The cells incubated in the presence of the control medium secreted quite high quantities of progesterone, about $500 \mathrm{ng} / \mathrm{ml} /$ ovary after 4 days. This level of secretion is the index of a luteal differentiation of the cells. The medium which contained $50 \%$ of pig FF and a mean of $276 \mathrm{ng}$ progesterone $/ \mathrm{ml}$ before incubation, considerably stimulated this secretion, even to levels of $3000 \mathrm{ng} / \mathrm{ml} /$ ovary after incubation for 4 days. All the levels of oestradiol- $17 \beta$ induced a secretion of progesterone which was about three times $(1500 \mathrm{ng})$ that of the controls for the same period of incubation. When incubated for 4 days in the presence of oestrogen-free FF or in dialysed fetal calf serum, the cells secreted a similar amount of progesterone to that secreted by control cells (about 500 to 600 $\mathrm{ng} / \mathrm{ml}$ /ovary). 
PILITY 1
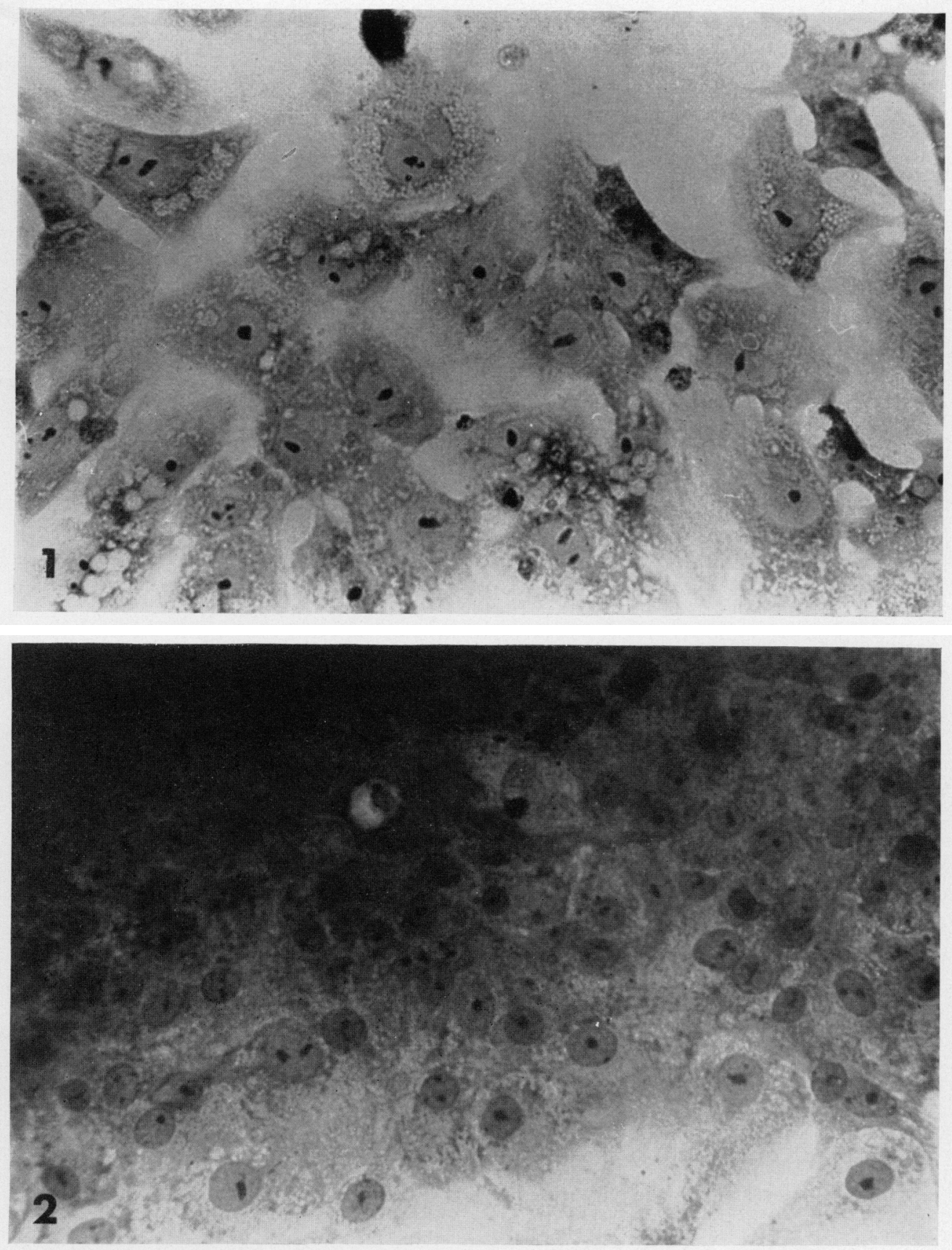

Fis, 1. Ligh micrograph of rat grantosil cells after 4 daws of culture in control medium. $\times 2.50$.

lici. 2. Light micrograph of rat granulosa cells after 4 dats of culume in medium conlaining $50 "$ " total follicular thuid. Note the difference in the size of the cells compared to thowe of rig. 1. $\times 2.50$.

faring $p .456$ 
PI.IIL: 2
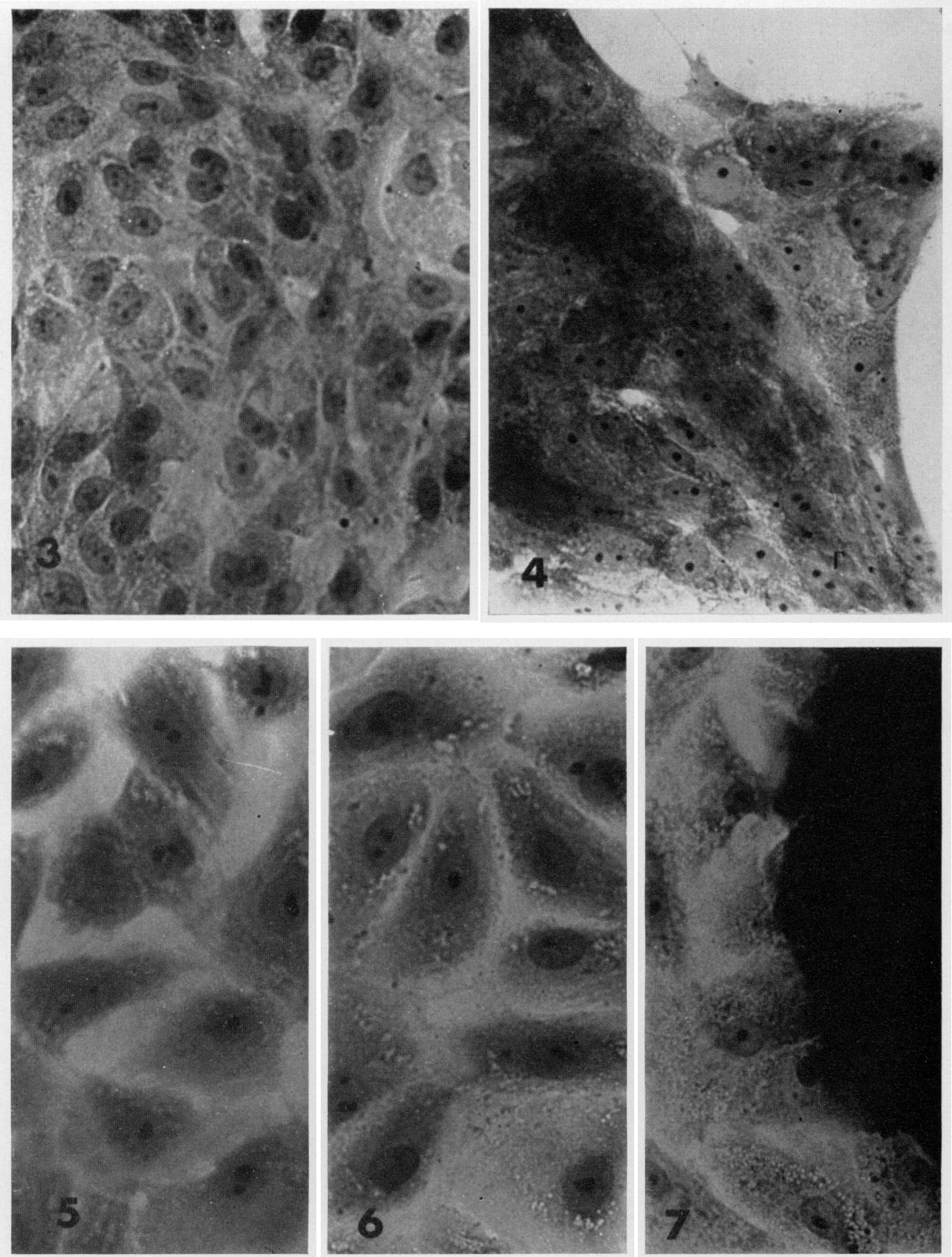

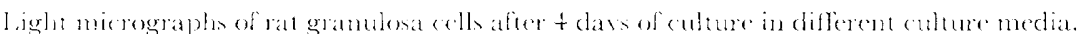
$\times 2.010$.

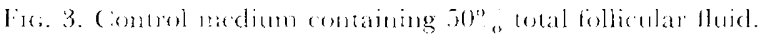

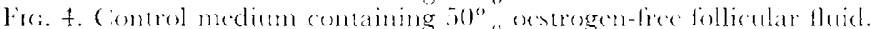

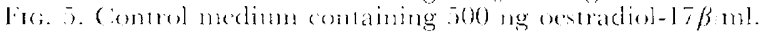

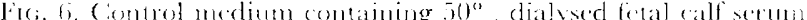

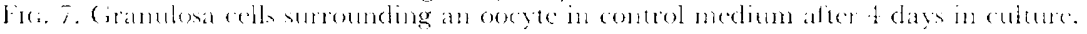


These results, expressed in ng progesterone secreted per ovary and per day after subtraction of the quantity of progesterone present before incubation, are summarized in Text-fig. 1. The differences in the secretory activity of the cells when incubated in the control medium, dialysed fetal calf serum, or oestrogenfree $\mathrm{FF}$ were not significant.

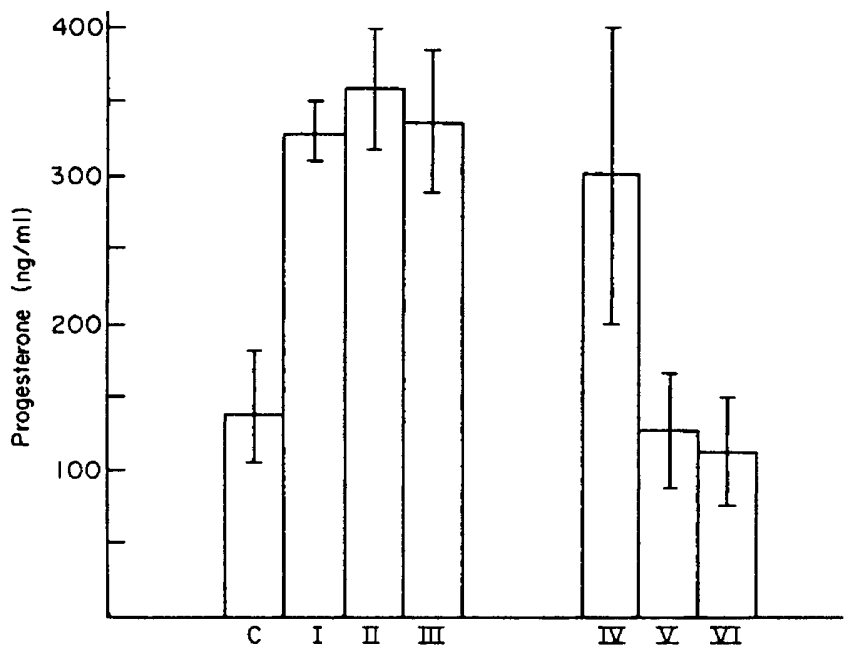

TExT-Fig. 1. The effect of oestradiol and follicular fluid on the mean daily level of progesterone secretion by rat granulosa cells cultured in vitro for 4 days. Vertical bars represent \pm S.E. C, control medium; I, control medium containing 50 ng oestradiol$17 \beta / \mathrm{ml}$; II, control medium containing $100 \mathrm{ng}$ oestradiol-17 $7 / \mathrm{ml}$; III, control medium containing $500 \mathrm{ng}$ oestradiol-17 $7 / \mathrm{ml}$; IV, total follicular fluid, $50 \% ; \mathrm{V}$, oestrogen-free follicular fluid, $50 \%$; VI, dialysed fetal calf serum, $50 \%$.

\section{DISCUSSION}

After culture for 4 days in control medium with or without oestradiol or in dialysed fetal calf serum, the morphology of the cells changed considerably. The cells acquired new cytological characteristics which we regard as criteria for their luteal differentiation: an increase in the size of the cells, the appearance of granules and lipid droplets in the cytoplasm, and the appearance of large and prominent nucleoli. These criteria are similar to those used by Channing $(1970 \mathrm{c})$ to characterize luteinization when culturing the granulosa cells of human, mare and sow follicles. Channing specified that luteinization was only possible when the cells were obtained from large preovulatory follicles or when they were incubated in the presence of FSH and LH. Rat granulosa cells are also stimulated by the preovulatory release of endogenous LH (Strauss \& Meyer, 1962); we can thus affirm that the cells certainly undergo luteal differentiation in these conditions.

The characteristics described above do not appear in cells which have been incubated in the presence of either total or oestrogen-free FF, or in the few cellular layers surrounding an oocyte. Nekola \& Nalbandov (1971) have observed the same cytological differences whether rat granulosa cells in culture are in direct contact with an oocyte or not. It seems evident from our results, 
therefore, that the FF profoundly modifies the development of granulosa cells in culture, particularly as regards their size and the appearance of their nucleoli. Nalbandov (1970) suggested that the oocyte might release a 'luteinization inhibitor', a factor which should therefore be present in the FF. The difference in the behaviour of the cells in the presence of FF compared to that of cells incubated in control medium may be due to the presence of this factor.

Studies on cows (Lutwak-Mann, 1954; Caravaglios \& Cilotti, 1957; Desjardins, Kirton \& Hafs, 1966), women (Manaran-Pangan \& Menge, 1971), rabbits (David, Frenkel \& Kraicer, 1973), and rats (Beck \& Shelden, 1972) have shown that the composition of FF resembles that of blood plasma, though the protein content of FF is higher; it has not as yet been possible, however, to detect a proteinaceous or antigenic component specific to FF. The high concentration of protein in this fluid seems unlikely to be responsible for the difference in the behaviour observed since the cells incubated in dialysed fetal calf serum undergo identical changes to those of the control cells. It could, however, explain the low rate of adhesion of the cells incubated in this serum or in total or oestrogen-free FF. Weiss (1964) and Takeichi (1971) have shown that the presence of blood serum in culture media decreases the ability of cells to adhere to a 'support' (or increases their detachment) and this phenomenon is linked to the high concentration of proteins in the serum.

In the mare and the ewe, Short $(1961,1962)$ found that all the steroidal components in the chain for the synthesis of the female hormones were present in the $F F$, oestradiol- $17 \beta$ being present in the highest concentration. In our laboratory, an assay of the oestradiol-17 $\beta$ present in pig FF by the double competitive protein-binding method of Robertson, Mester \& Kellie (1971) showed that this fluid contained an average of $201 \pm 57 \mathrm{ng} / \mathrm{ml}$. The marked stimulation of the progesterone secretion by cells incubated in the presence of FF is believed to be due to the high concentration of oestradiol-17 $\beta$ in this fluid. In the present study, it has been shown that exogenous oestradiol stimulates progesterone secretion by rat granulosa cells in culture, and that, after adsorption of the oestrogens by dextran-coated charcoal, the FF no longer stimulates this secretion. As far as is known, this effect of the FF on the synthesis of progesterone has only been observed by YoungLai (1972), who noted that the conversion of pregnenolone to progesterone by equine granulosa cells in vitro was improved if the incubation medium contained FF rather than blood plasma from the same species. It is known that oestrogens can have a stimulatory effect on luteal function; they stimulate progesterone secretion by CL in vivo and increase their life-span in the rabbit (Keyes \& Nalbandov, 1967; Johnson \& Murray, 1974), rat (Takayama \& Greenwald, 1973; Uchida, Kadowaki, Miyake \& Wakabayashi, 1973; Abdi \& Das, 1972) and hamster (Greenwald, 1973). Fuller \& Hansel (1971) obtained a stimulation of progesterone synthesis by rabbit luteal cells in vitro, using $5 \mu \mathrm{g}$ oestradiol. Goldenberg, Bridson \& Kohler (1972) obtained the same result for pig granulosa cells incubated in the presence of $10 \mu \mathrm{g}$ oestradiol or $10 \mu \mathrm{g}$ diethylstilboestrol, with or without HCG. The present findings confirm the results of these authors and indicate that oestradiol (even as little as 50 to $500 \mathrm{ng} / \mathrm{ml}$ ) has a direct luteotrophic effect.

The presence of oestradiol in the control medium or in the FF does not how- 
ever seem necessary for the secretion of progesterone by the granulosa cells, since, when incubated in the control medium alone or in oestrogen-free $F F$, the cells were able to secrete progesterone.

Channing (1973) has shown that the luteal differentiation of the granulosa cells is dependent on the appearance in these cells of complexes of LH linked to their receptors. It is possible that the FF inhibits this differentiation through a factor which competes with these complexes. In support of this hypothesis, Channing has also shown that in pig granulosa cells, the stimulation of the synthesis of cyclic AMP necessary to luteinization and observed in the presence of $\mathrm{LH}$, is inhibited in the presence of FF. After ovulation or in culture conditions, the absence of this inhibiting factor and the presence of LH in these cells would allow the start of the process of luteal differentiation. Further evidence regarding the origin and chemical nature of this inhibiting factor is, however, still required.

\section{ACKNOWLEDGMENTS}

This work has been supported by a Grant (No. 7100156) from the Ford Foundation to Dr Alexandre Psychoyos, and a fellowship of the Délégation Générale à la Recherche Scientifique et Technique to the author. The author is indebted to Dr A. Psychoyos for his advice and for his interest in this work. The author is also grateful to Dr E. Milgrom for the generous supply of the progesterone-binding plasma protein, used for the progesterone assays, and wishes to thank Miss D. Martel for carrying out the oestradiol assays on pig follicular fluid.

\section{REFERENGES}

AbDi, P. N. \& DAs, A. C. (1972) Effect of oestrogen administration on the corpora lutea of albino rats. Indian J. med. Res. 60, 1779-1784.

Beck, L. R. \& Shelden, R. M. (1972) Antigenicity of rat follicular fluid. Fert. Steril. 23, 910-914.

BerNard, J. (1972) Lutéinisation in vitro des cellules granulosaires du Rat; effet de l'actinomycine D. C. r. Séanc. Soc. Biol. 166, 840-843.

BerNard, J. (1973) Effet du liquide folliculaire sur la luténisation in vitro des cellules granulosaires du Rat. C. r. Séanc. Soc. Biol. 167, 882-885.

Caravaglios, R. \& Gilott, C. (1957) A study of the proteins in the follicular fluid of the cow. $\mathcal{J}$. Endocr. 15, 273-278.

Channing, C. P. (1969a) Steroidogenesis and morphology of human ovarian cell types in tissue culture. 7. Endocr. 45, 297-308.

Ghanning, G. P. (1969b) Tissue culture of equine ovarian cell types: culture methods and morphology. 7. Endocr. 43, 381-390.

Channing, C. P. (1970a) Effect of stage of the menstrual cycle and gonadotrophins on luteinization of Rhesus monkey granulosa cells in culture. Endocrinology, 87, 49-60.

Channing, C. P. (1970b) Effect of stage of the estrous cycle and gonadotrophins upon luteinization of porcine granulosa cells in culture. Endocrinology, 87, 156-164.

Channing, C. P. (1970c) Influences of the in vivo and in vitro hormonal environment upon luteinization of granulosa cells in culture. Recent Progr. Horm. Res. 26, 589-622.

Ghanning, C. P. (1973) Factors involved in luteinization in vitro. In Proc. 4th Int. Cong. Endocrinolcgy, pp. 340-345. Ed. R. O. Scow. Excerpta Medica, Amsterdam.

David, A., Frenkel, G. \& Kraicer, P. F. (1973) Chemical composition of rabbit follicular fluid. Fert. Steril. 24, 227-229.

Desjardins, G., Kirton, K. T. \& Hafs, H. D. (1966) Some chemical, immunochemical and electrophoretic properties of bovine follicular fluid. 7. Reprod. Fert. 11, 237-244.

El-Fouly, M. A., Cook, B., Nekola, M. \& Nalbandov, A. V. (1970) Role of the ovum in follicular luteinization. Endocrinology, 87, 288-293. 
Fuller, G. B. \& HANSEL, W. (1971) Estrogen-stimulated progesterone synthesis by rabbit corpora lutea in vitro. Proc. Soc. exp. Biol. Med. 137, 539-542.

Goldenberg, R. L., Bridson, W. E. \& Kohler, P. O. (1972) Estrogen induced progesterone synthesis in granulosa cells in culture. In Proc. 4th Congr. Endocrinology, Abstract No. 434, p. 172. Int. Congr. Ser. No. 256, Excerpta Medica, Amsterdam.

Greenwald, G. S. (1973) Further evidence for a luteotropic complex in the hamster: progesterone determination of plasma and corpora lutea. Endocrinology, 92, 235-242.

GRoB, H. S. (1971) Monolayer culture of ovarian follicular elements derived from isolated mouse follicles. Biol. Reprod. 5, 207-213.

Johnson, M. H. \& Murray, F. A. (1974) Effect of dosage of oestradiol-17 $\beta$ on the life-span of the rabbit corpus luteum. Experientia, 30, 308-309.

Keyes, P. L. \& Nalbandov, A. V. (1967) Maintenance and function of corpora lutea in rabbits depend on estrogen. Endocrinology, 80, 938-946.

Lutwak-MANN, C. (1954) Note on the chemical composition of bovine follicular fluid. F. agric. Sci., Camb. 44, 477-490.

Manaran-Pangan, S. \& Menge, A. C. (1971) Immunological studies on human follicular fluid. Fert. Steril. 22, 367-372.

MURPHy, B. E. P. (1967) Some studies of the protein binding of steroids and their applications to the routine micro- and ultramicro-measurement of various steroids in body fluids by competitive protein-binding radioassay. F. clin. Endocr. Metab. 27, 973.

Nalbandov, A. V. (1970) Interaction between oocytes and follicular cells. In Oogenesis, pp. 513-522. Eds. J. D. Biggers and A. E. Schuetz. University Park Press, Baltimore.

Nekola, M. V. \& Nalbandov, A. V. (1971) Morphological changes of rat follicular cells as influenced by oocytes. Biol. Reprod. 4, 154-160.

Nicosia, S. V. (1972) Luteinization of rabbit preovulatory granulosa cells cultured in vitro in presence of follicular oocytes. I. Growth characteristics and progestin biosynthesis. Fert. Steril. 23, 791-801.

PICHon, M. F. \& MILGRom, E. (1973) Competitive protein-binding assay of progesterone without chromatography. Steroids, 21, 335-346.

Rosertson, D. M., Mester, J. \& Kellie, A. E. (1971) A double competitive binding method of measuring oestradiol from menstrual cycle plasma with and without the prior purification of oestradiol. Acta endocr., Copenh. 68, 513-522.

Schomberg, D. W. (1969) The concept of a uterine luteolytic hormone. In The Gonads, pp. 383-414. Ed. K. W. McKerns. North-Holland Publishing Co., Amsterdam.

SHORT, R. V. (1961) Steroid concentrations in the follicular fluid of mares at various stages of the reproductive cycle. F. Endocr. 22, 153-163.

SHORT, R. V. (1962) Steroid concentrations in the follicular fluid of the cow. F. Endocr. 23, 401-411.

StRAuss, W. F. \& MEYER, R. K. (1962) Neural timing of ovulation in immature rats treated with gonadotrophin. Science, N.Y. 137, 860-861.

Takayama, M. \& Greenwald, G. S. (1973) Direct luteotropic action of estrogen in the hypophysectomized-hysterectomized rat. Endocrinology, 92, 1405-1413.

TAKeichi, M. (1971) Changes in the properties of cell-substrate adhesion during cultivation of chicken fibroblasts in vitro in a serum-free medium. Expl Cell Res. 68, 88-96.

Uchida, K., Kadowaki, M., Mryake, T. \& Wakabayashi, K. (1973) Further studies on the luteotropic action of estrogen in rats. Endocr. jap. 20, 103-110.

WEIss, L. (1964) Studies on cellular adhesion in tissue culture. VII. Surface activity and cell detachment. Expl Cell Res. 33, 277-288.

YoungLAI, E. V. (1972) The influence of follicular fluid and plasma on the steroidogenic activity of equine granulosa cells. F. Reprod. Fert. 28, 95-97. 